\title{
KARAKTERISTIK BATUAN INDUK HIDROKARBON DAN HUBUNGANNYA DENGAN REMBESAN MINYAK DI LAPANGAN MINYAK CIPLUK, KABUPATEN KENDAL, PROVINSI JAWA TENGAH
}

\section{THE CHARACTERISTIC OF HYDROCARBON SOURCE ROCK AND ITS RELATIONSHIP TO OIL SEEPAGE IN THE CIPLUK OILFIELD, KENDAL REGENCY, CENTRAL JAVA PROVINCE}

\author{
Praptisih \\ Pusat Penelitian Geoteknologi-LIPI, \\ JI. Sangkuriang Komplek LIPI Gedung 70 Bandung \\ praptie3103@yahoo.com
}

\begin{abstract}
ABSTRAK
Lapangan minyak Cipluk di Cekungan Serayu Utara merupakan lapangan minyak tua jaman Belanda yang telah ditinggalkan, dan belum pernah dilakukan analisis geokimia minyak atau batuan yang diduga sebagai batuan sumber. Tujuan penelitian ini adalah untuk mengetahui karakteristik batuan induk dari Formasi Kerek dan Formasi Penyatan dan hubungannya dengan rembesan minyak bumi di Sojomerto. Metodologi yang dilakukan adalah penelitian lapangan dan analisis laboratorium. Dari analisis batuan induk diperoleh nilai Kandungan Organik Karbon (TOC) yang berkisar dari $0,72 \%$ sampai $7,97 \%$, yang menunjukan kategori sedang hingga sangat baik untuk mampu membentuk hidrokarbon. Berdasarkan pirolisis rock eval tingkat kematangan thermal dari conto berada dalam kisaran belum matang hingga matang, sedangkan tipe kerogennya termasuk ke dalam tipe III. Hasil analisis geokimia conto minyak menunjukan minyak yang telah mencapai tingkat matang, batuan induk minyak diendapkan pada lingkungan estuarin atau lakustrin dangkal dengan material organik yang berasal dari tumbuhan daratan. Rembesan minyak di Sojomerto tidak mempunyai korelasi geokimia dengan conto batuan induk dari Formasi Kerek atau Formasi Penyatan.
\end{abstract}

Kata kunci: Formasi Kerek, Formasi Penyatan, karakteristik batuan induk, rembesan minyak

\section{ABSTRACT}

The Cipluk oil field located in the North Serayu Basin is the oil field in the Dutch Era and has been abandoned and geochemical analysis of oil and rock predicted as source rocks has never been done. The propose of the study was to detemine source rock potential of Kerek and Penyatan Formation and also to know geochemical characteristic of oil seepage at Sojomerto. The method used in this study are a field research and taking samples of mudstone and oil seepage tobe analyzed in the laboratory. Results of the analysis indicate that the source rock has a TOC value 0,72\%-7,97\% which in the catagory moderate to very good to be able to form hidrocarbon. Based on the Rock Eval Pirolysis the levels of thermal maturity of the samples in range of immature to mature and the type of kerogen is type III. Geochemical analysis of oil sample show that the levels of maturity is mature and the oil source rock deposited in estuarine or shallow lacustrine environment with organic material derived from land plants. Oil seepage at Sojomerto no geochemical correlation with source rock samples.

Keywords: Kerek Formation, Penyatan Formation, source rock characteristic, Oil seepage

\section{PENDAHULUAN}

Penelitian batuan induk dilakukan di daerah Kabupaten Kendal, Provinsi Jawa
Tengah. Di daerah tersebut terdapat lapangan minyak Cipluk yang merupakan lapangan minyak tua peninggalan Belanda yang sampai sekarang masih dimanfaat- 
kan oleh masyarakat setempat. Lapangan minyak Cipluk termasuk dalam Cekungan Serayu Utara (North Serayu Basin), secara regional menerus ke Cekungan Bogor di Jawa Barat, dan ke Zona Kendeng di Jawa Timur. Jalur ini membentang di sepanjang Pulau Jawa yang disebut Bogor-North Serayu-Kendeng Deep Water Zone (Setyana, 2004). Keberadaan rembesan minyak di daerah Kendal membuktikan di daerah tersebut terdapat batuan induk efektif (effective source rock). Permasalahannya adalah batuan induk mana yang menjadi sumber rembesan minyak di daerah tersebut.

Penelitian ini bertujuan untuk mengidentifikasi karakteristik batuan induk di daerah Liangan serta hubungannya dengan rembesan minyak bumi di daerah Sojomerto, Kecamatan Singorejo. Dengan mengetahui lingkungan pengendapan dan karakteristik rembesan minyak, diharapkan dapat diketahui hubungan antara rembesan minyak dengan formasi batuan yang tersingkap di sekitar lokasi rembesan tersebut.

\section{METODOLOGI}

Penelitian ini diawali dengan studi pustaka yang berkaitan dengan cekungan sedimen yang telah terbukti mengandung hidrokarbon. Metode pengumpulan data yang dilakukan adalah penelitian lapangan dan laboratorium. Penelitian lapangan meliputi pengamatan litostratigrafi Formasi Kerek dan Formasi Penyatan, serta pengambilan conto batuan dan rembesan minyak. Penelititian laboratorium terdiri dari dua jenis analisis geokimia, yang pertama adalah analisis geokimia batuan induk yang meliputi analisis kandungan bahan organik total atau "total organic carbon content" (TOC). Analisis pirolisis hanya dilakukan terhadap conto batuan yang mempunyai nilai TOC lebih besar dari $0,5 \%$, tujuan analisis pirolisis adalah untuk mengetahui Production Index (PI), tipe dari kerogen (indek Hidrogen) dan Temperatur maksimum (C) pembentukan hidrokarbon dari kerogen. Kedua, analisis karakteristik geokimia rembesan minyak bumi meliputi analisis Gas Cromatography (GC).

\section{GEOLOGI DAERAH PENELITIAN}

Geologi daerah penelitian termasuk dalam Peta Geologi Lembar Magelang-Semarang skala 1 : 100.000 (Pusat Penelitian dan Pengembangan Geologi, 1996). Stratigrafi daerah penelitian dari tua ke muda disusun oleh Formasi Kerek, Formasi Penyatan, Formasi Kaligetas, Formasi Damar dan endapan aluvium. Di samping itu ditemukan juga batuan terobosan basal yang berumur Miosen Tengah.

Formasi Kerek terdiri dari perselingan batulempung, napal, batupasir tufaan, konglomerat, breksi vulkanik dan batugamping. Batulempung berwarna kelabu tua yang sebagian bersisipan batulanau atau batupasir, setempat mengandung fosil foram, moluska dan koral-koral koloni, berumur Miosen Tengah.

Formasi Penyatan terdiri dari batupasir, breksi, tuf, batulempung dan aliran-aliran lava. Batupasir tufaan dan breksi vulkanik (aliran dan lahar) tampak dominan. Secara setempat ditemukan aliran lava, batulempung marine dan napal. Formasi ini berumur Miosen Tengah-Pliosen. Bagian atas dari Formasi Penyatan menjemari dengan Formasi Kaligetas dan Formasi Damar.

Formasi Kaligetas disusun oleh breksi vulkanik, aliran lava, tuf, batupasir tufaan dan batulempung. Setempat bagian bawahnya ditemukan batulempung mengandung moluska dan batupasir tufaan. Seumur dengan Formasi Kaligetas adalah Formasi Damar yang disusun oleh batupasir tufaan, konglomerat, dan breksi vulkanik. Umur Formasi Kaligetas dan Formasi Damar adalah Plio-Plistosen. Endapan paling muda pada daerah ini adalah endapan aluvium yang terdiri dari kerikil, kerakal, pasir, lanau dan lempung (Gambar 1). 


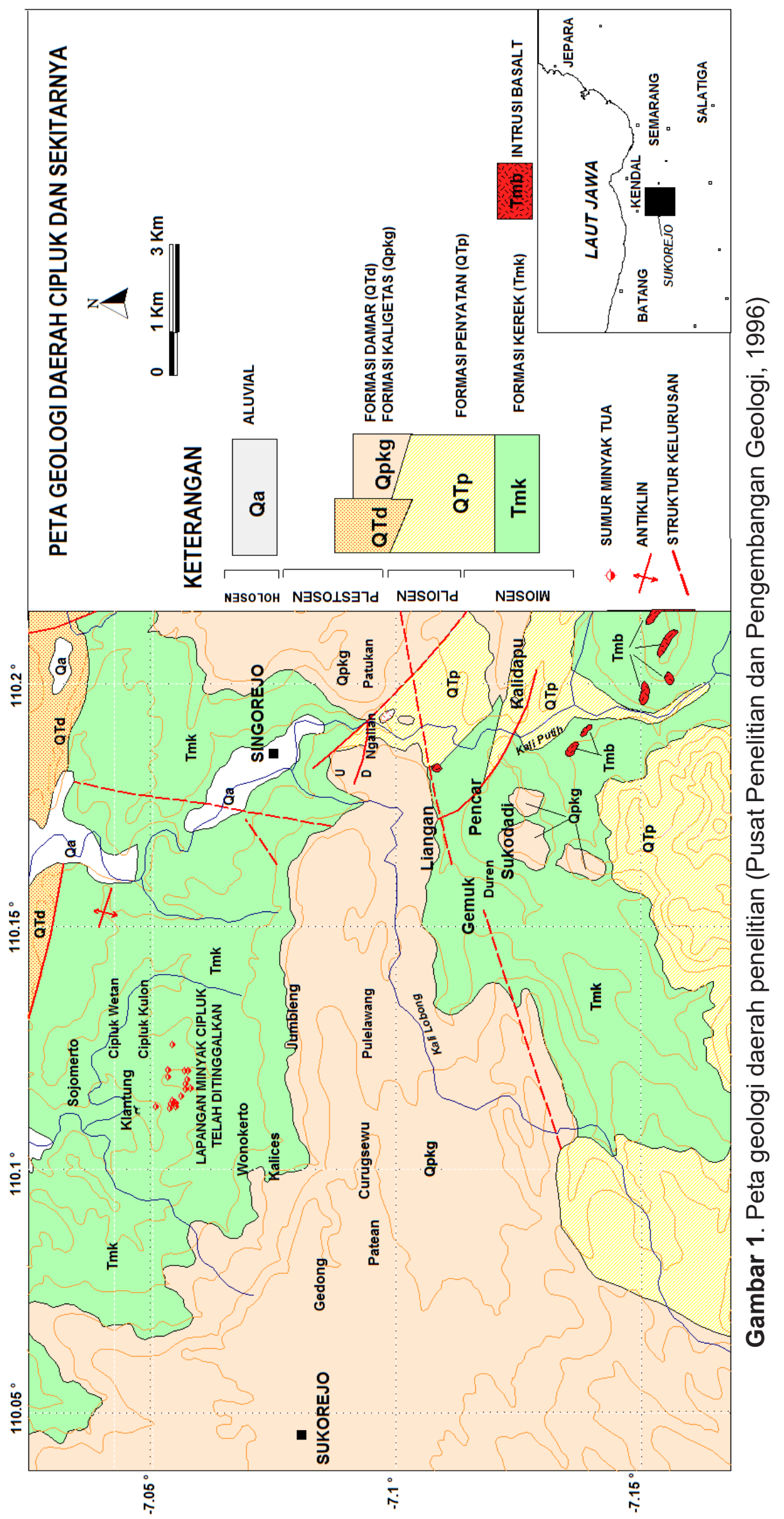




\section{MAKALAH ILMIAH}

\section{ANALISIS GEOKIMIA}

Analisis batuan induk untuk mengetahui potensi dan kematangan termal hidrokarbon dilakukan terhadap 12 conto batu lempung dan batulanau dari Formasi
Kerek dan Formasi Penyatan. Analisis geokimia yang dilakukan meliputi kandungan organik karbon (TOC) sebanyak 12 conto dan Rock Eval Pirolisis sebanyak 7 conto yang lokasinya dapat dilihat pada Gambar 2. Hasil analisis dapat dilihat pada tabel 1 dan 2 .

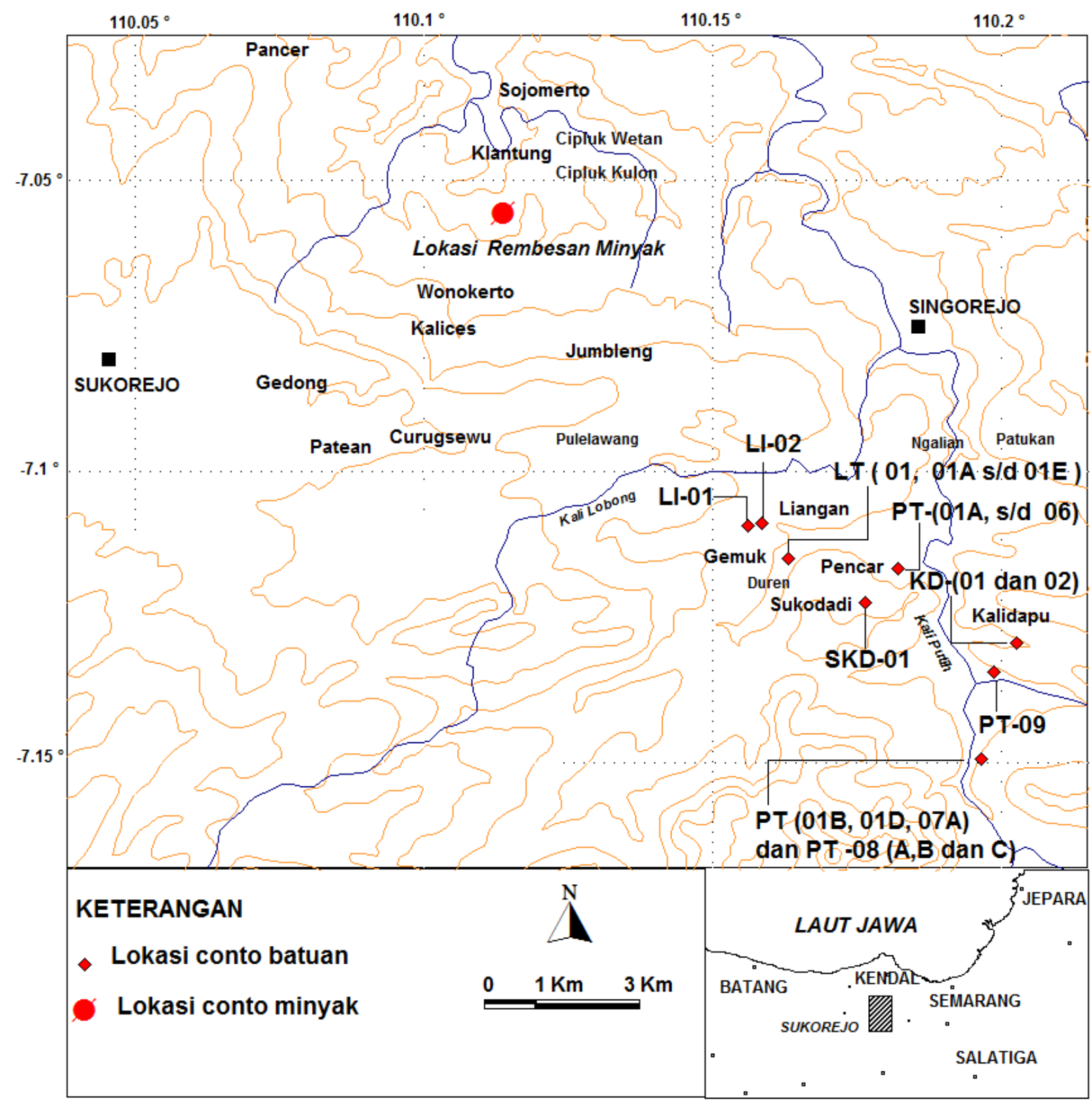

Gambar 2. Lokasi pengambilan conto batulempung dan rembesan minyak bumi. 


\section{MAKALAH ILMIAH}

Tabel 1. Hasil Analisis TOC

\begin{tabular}{|c|c|c|c|c|c|}
\hline No & $\begin{array}{l}\text { No. } \\
\text { Conto }\end{array}$ & Lokasi & Formasi & Litologi & TOC ( \%) \\
\hline 1 & LT 01 & $\begin{array}{l}\text { Sungai Lutut, } \\
\text { Desa Duren }\end{array}$ & Formasi Kerek & Batulempung & 0,87 \\
\hline 2 & LT $01 \mathrm{D}$ & $\begin{array}{l}\text { Sungai Lutut, } \\
\text { kampung } \\
\text { Liangan }\end{array}$ & Formasi Kerek & Batulanau & 2,08 \\
\hline 3 & PT 01 & Kali Putih & Formasi Kerek & Batulanau & 0,41 \\
\hline 4 & PT $01 \mathrm{D}$ & Kali Putih & Formasi Kerek & Batulanau & 0.96 \\
\hline 5 & PT 04 & Kali Putih & Formasi Kerek & Batulempung & 0,20 \\
\hline 6 & PT $07 \mathrm{~B}$ & Kali Dengkeng & Formasi Kerek & Batulempung & 1,45 \\
\hline 7 & PT 08 B & Kali Putih & Formasi Kerek & Batulempung & 1,41 \\
\hline 8 & PT $09 \mathrm{C}$ & Kali Putih & Formasi Kerek & Batulempung & 0,10 \\
\hline 9 & LI 01 & Liangan & Formasi Kerek & Batulanau & 7,97 \\
\hline 10 & LI $02 \mathrm{~B}$ & Liangan & Formasi Kerek & Batulempung & 0,72 \\
\hline 11 & KD 02 & Kalidapu & Formasi Penjatan & Batulanau & 0,20 \\
\hline 12 & SKD 01 & Sukodadi & Formasi Penjatan & Batulempung & 0,06 \\
\hline
\end{tabular}

Tabel 2. Analisis Rock Eval pirolisis

\begin{tabular}{|c|c|c|c|c|c|c|c|c|c|c|c|}
\hline \multirow[t]{2}{*}{ No } & \multirow[t]{2}{*}{ Sampel } & \multirow[t]{2}{*}{ Litologi } & \multirow{2}{*}{$\begin{array}{c}\text { TOC } \\
(\%)\end{array}$} & S1 & S2 & S3 & PY & \multirow[t]{2}{*}{$\mathrm{PI}$} & \multirow{2}{*}{$\begin{array}{c}\text { Tmax } \\
\left({ }^{\circ} \mathrm{C}\right)\end{array}$} & \multirow[t]{2}{*}{$\mathrm{HI}$} & \multirow[t]{2}{*}{$\mathrm{Ol}$} \\
\hline & & & & \multicolumn{4}{|c|}{$\mathrm{Mg} / \mathrm{g}$} & & & & \\
\hline 1 & LT 01 & Batulempung & 0,87 & 0,03 & 0,75 & 1,70 & 0,78 & 0,04 & 342 & 86 & 195 \\
\hline 2 & LT $01 \mathrm{D}$ & Batulanau & 2,08 & 0,04 & 0,66 & 1,37 & 0,70 & 0,06 & 426 & 32 & 66 \\
\hline 3 & PT $01 \mathrm{D}$ & Batulanau & 0.96 & 0,03 & 0,71 & 2,37 & 0,74 & 0,04 & 433 & 74 & 246 \\
\hline 4 & PT $07 \mathrm{~B}$ & Batulempung & 1,45 & 0,06 & 1,77 & 0,97 & 1,83 & 0,02 & 435 & 122 & 67 \\
\hline 5 & PT 08 B & Batulempung & 1,41 & 0,04 & 1,65 & 0,59 & 1,69 & 0,02 & 434 & 117 & 42 \\
\hline 6 & LI 01 & Batulanau & 7,97 & 0,15 & 1,43 & 8,62 & 1,58 & 0,09 & 398 & 18 & 108 \\
\hline 7 & LI 02 B & Batulempung & 0,72 & 0,06 & 1,18 & 0,34 & 1,24 & 1,24 & 432 & 163 & 47 \\
\hline
\end{tabular}

Keterangan :

S1: Free Hydrocarbon, S2 : Pyrolysable Hydrocarbon, S3 : Organic $\mathrm{CO}_{2}$, Oil Production Index $=$ Transformation Ratio $=S 1 /(S 1+S 2)$, Tmax $=$ Temperature of Maximum, OI : Oxigen Index $=(S 2 / T O C x 100), H I:$ Hidrogen Index $=(S 2 / T O C x 100), P Y:$ Total Generation Potential

\section{PEMBAHASAN}

\section{Potensi batuan induk}

Nilai TOC pada Formasi Kerek berkisar antara $0,72 \%$ sampai $7,97 \%$, nilai tersebut menunjukkan bahwa batuan induk berpotensi sedang hingga sangat baik untuk membentuk hidrokarbon, sedangkan pada Formasi Penyatan berkisar antara $0,06 \%$ sampai $0,20 \%$, nilai tersebut menunjukkan batuan induk berpotensi rendah untuk membentuk hidrokarbon (Waples, 1985).

Potensi hidrokarbon Formasi Kerek di daerah penelitian dapat dilihat pada diagram kandungan organik karbon (TOC) versus Total Generation Potential (PY) (Gambar 3). Nilai PY yang berkisar antara $0,70 \mathrm{HC} / \mathrm{g}$ rock sampai $1,24 \mathrm{mg} \mathrm{HC} / \mathrm{g}$ rock termasuk kategori rendah (poor). Hasil pengeplotan TOC versus PY pada conto yang dianalisis, sebanyak 6 conto menempati gas prone dan 1 conto pada batas antara oil prone dan gas prone (Rad, 1984). Batuan induk pada Formasi Kerek mempunyai nilai $\mathrm{HI}$ sebesar $32 \mathrm{HC} / \mathrm{g}$ rock sampai $163 \mathrm{mg} \mathrm{HC} / \mathrm{g}$ rock, berdasarkan klasifikasi Petter (1986) nilai indek hidrogen tersebut menunjukkan bahwa 6 conto (LT01, LT01D, PT01D, PT 07B, PT08B dan LI0) menghasilkan gas dan 1 conto (LIO2B) dapat menghasilkan minyak dan gas. 


\section{MAKALAH ILMIAH}

Kematangan termal Formasi Kerek (immature) sampai matang (mature). berdasarkan diagram $\mathrm{HI}$ versus Sedangkan tipe kerogen di daerah Temperatur Maksimum (Gambar 4), penelitian termasuk dalam tipe kerogen III. menunjukkan kategori belum matang

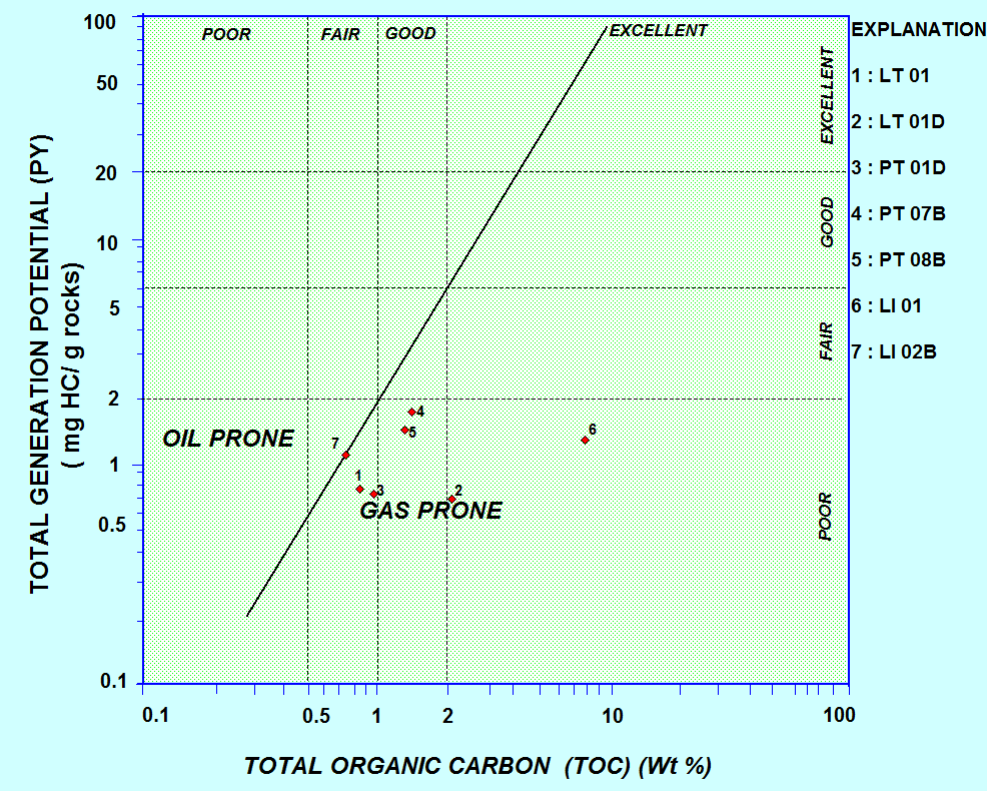

Gambar 3. Diagram TOC terhadap Total Generation Potential (PY) pada conto Formasi Kerek (Rad, 1984)

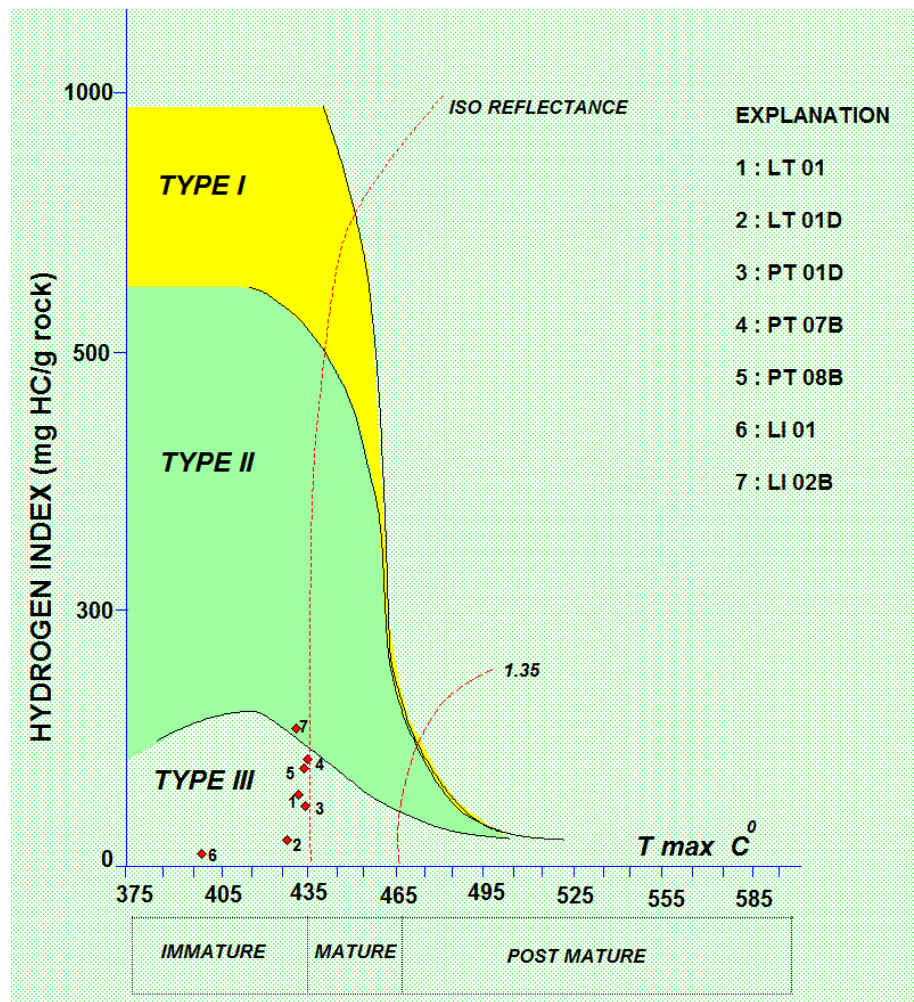

Gambar 4. Diagram $T_{\max }$ terhadap HI pada conto Formasi Kerek yang memperlihatkan tipe kerogen dan tingkat kematangan. (Espitalié, J., 1984, op.cit Mukhopadhyay, 1995) 


\section{Karakteristik geokimia rembesan minyak Cipluk}

Minyak Cipluk menunjukkan kandungan fraksi saturat jenuh yang sangat dominan yaitu $62,71 \%$, fraksi aromatik $8,23 \%$, fraksi polar $\left(\mathrm{NSO}_{5}\right) \quad 2,37 \%$, dan aspalthene $0,65 \%$. Total tingkat aspalthene yang rendah menunjukkan bahwa minyak di daerah ini sudah mengalami biodegradasi tingkat sedang (midly biodegraded). Rasio saturasi/aromatik yang relatif tinggi $(2,13)$ mengindikasikan karakter tipe parafinik sedang serta minyak matang (Tissot and Welte,1984) (Gambar 5).

\section{GC dan GCMS Biomarker}

Analisis gas kromatografi dilakukan pada fraksi whole extract $\left(\mathrm{C}_{5+}\right)$ pada conto minyak. GC ditunjukkan pada Gambar 6. Whole oil GC memberikan karakter kedudukan parafine normal yaitu $\mathrm{N} \mathrm{C}_{5}$ sampai $\mathrm{N} \mathrm{C}_{30+}$. $\mathrm{CH}_{4}$ oil menunjukkan light oil dengan batas alkana normal dari $\mathrm{C}_{5}$ sampai $\mathrm{C}_{24}$. Grafik data gas kromatografi menunjukkan rasio pristane/phytane yang tinggi yaitu 4,78 (Gambar 7), diperkirakan berasal dari batuan induk yang diendapkan pada lingkungan suboksik (midly ocxic) menunjukkan kerogen tipe III.

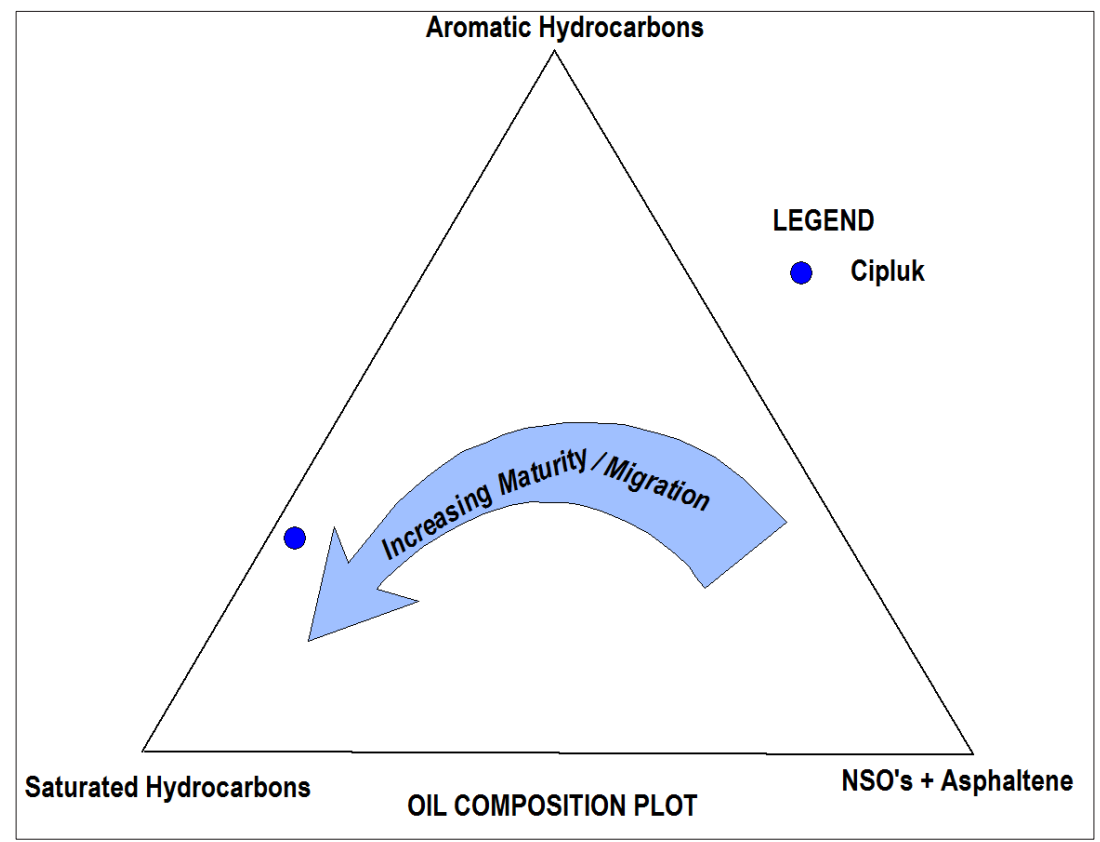

Gambar 5. Diagram komposisi fraksi, aromatik dan $\mathrm{NSO}_{5}+$ Aspalthene pada saturat minyak.

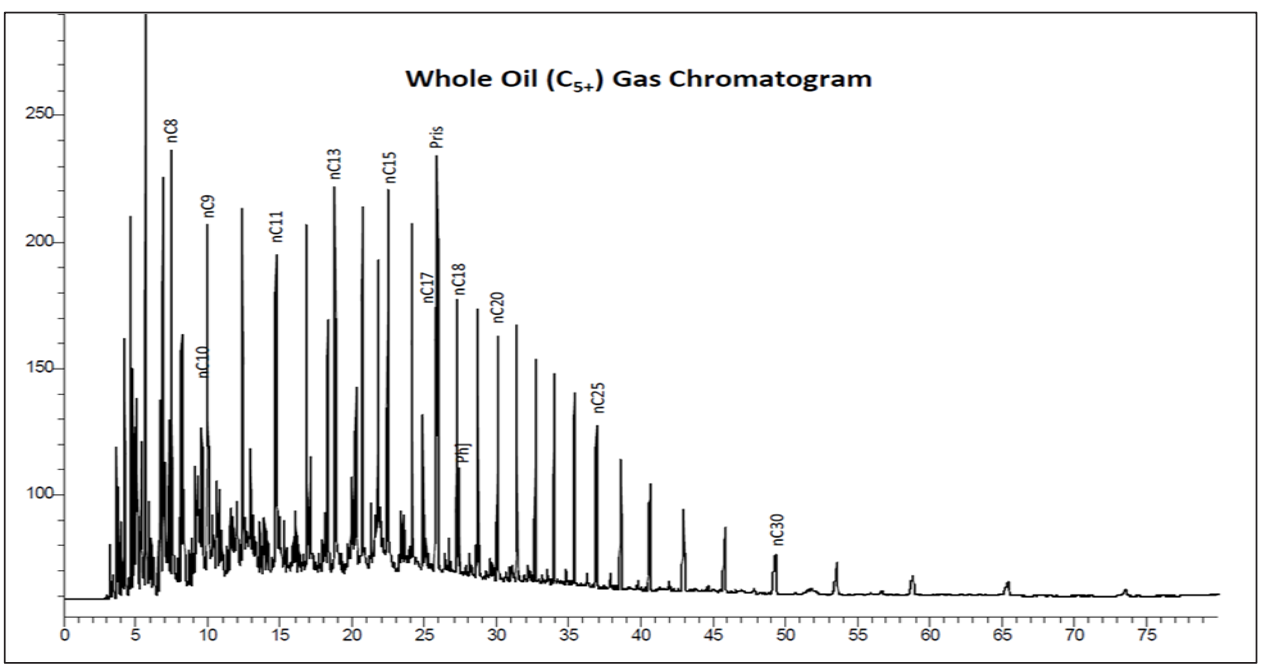

Gambar 6. Grafik Whole oil $\left(\mathrm{C}_{5+}\right)$ Gas Chromatogram 


\section{MAKALAH ILMIAH}

\section{Pristane/nC $\mathbf{C}_{17}$ versus Phytane/nC $\mathbf{P}_{18}$ Diagram}

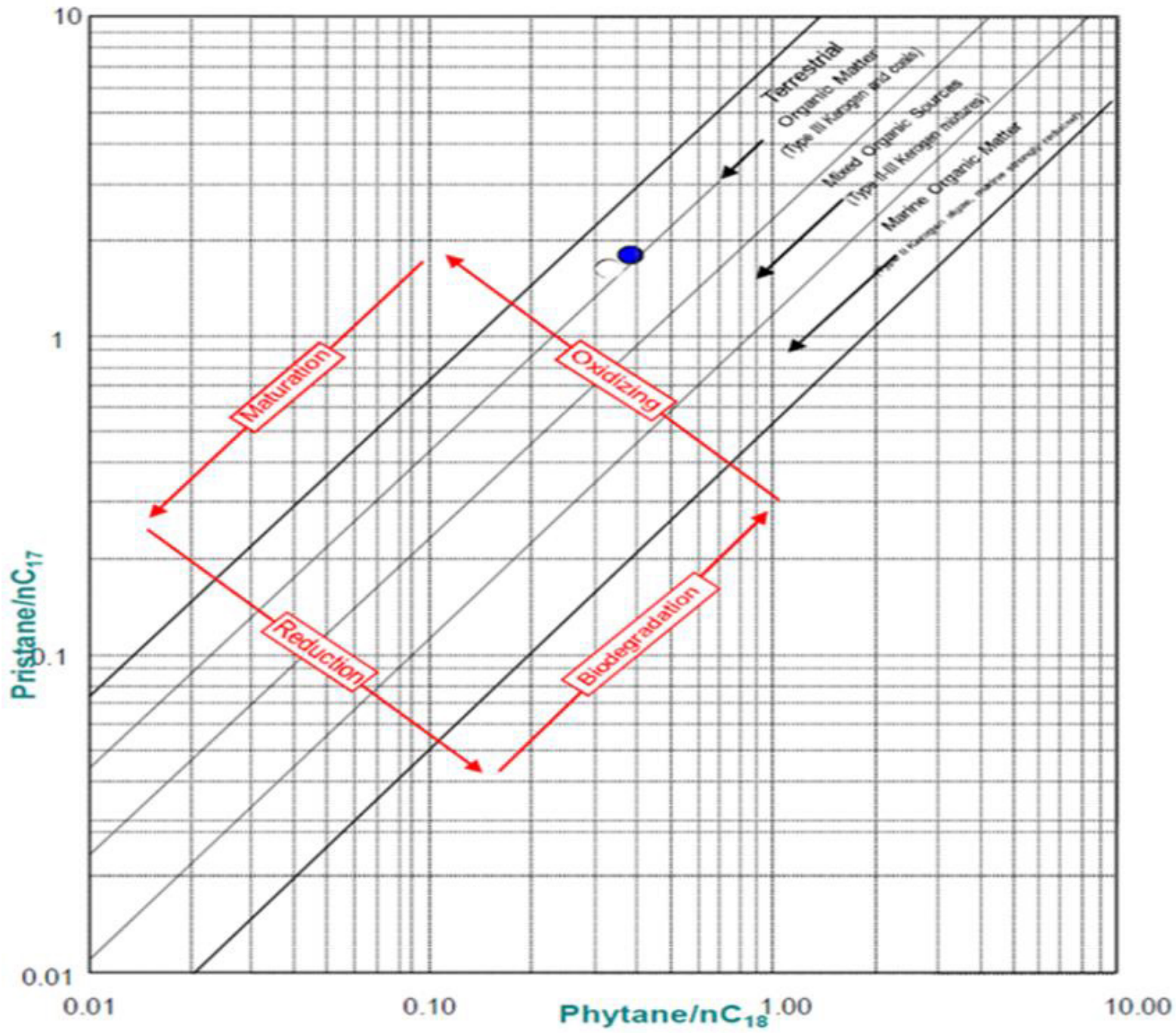

Gambar 7. Diagram pristane/ $\mathrm{C}_{17}$ versus phytane/ $\mathrm{C}_{18}$ (Connan and Cassou, 1980)

Fragmentogram massa m/z 191 (Gambar 8) menunjukkan distribusi bakteri $17 \alpha \beta(\mathrm{H})$ hopane yang relatif sama dengan $\mathrm{C} 30$ hopane sampai C 29 hopane. Hal ini menunjukkan bahwa conto minyak berasal dari fluvio deltaic. Hadirnya senyawa 18 $\alpha(\mathrm{H})$-oleanana yang relatif tinggi diperkirakan berasal dari tanaman angiosperm yang berumur Kapur atau lebih muda (Petter and K.E. Moldowan, 1993).

\section{Sterane $(\mathrm{m} / \mathrm{z} 217)$}

Distribusi normal sterane memperlihatkan C 27 sterane sebesar $27,90 \%$ kurang berlimpah, C 29 sterane mempunyai porsi yang lebih besar yaitu $38,69 \%$ hal ini menunjukkan bahwa material dari C 27 organiknya berasal dari darat. Gambar 9 menunjukkan lingkungan pengendapan batuan induk minyak bumi. Dari plot komposisi sterane pada segitiga Huang dan Meinchene, 1979 diperkirakan diendapkan pada lingkungan estuarin atau lakustrin dangkal. 


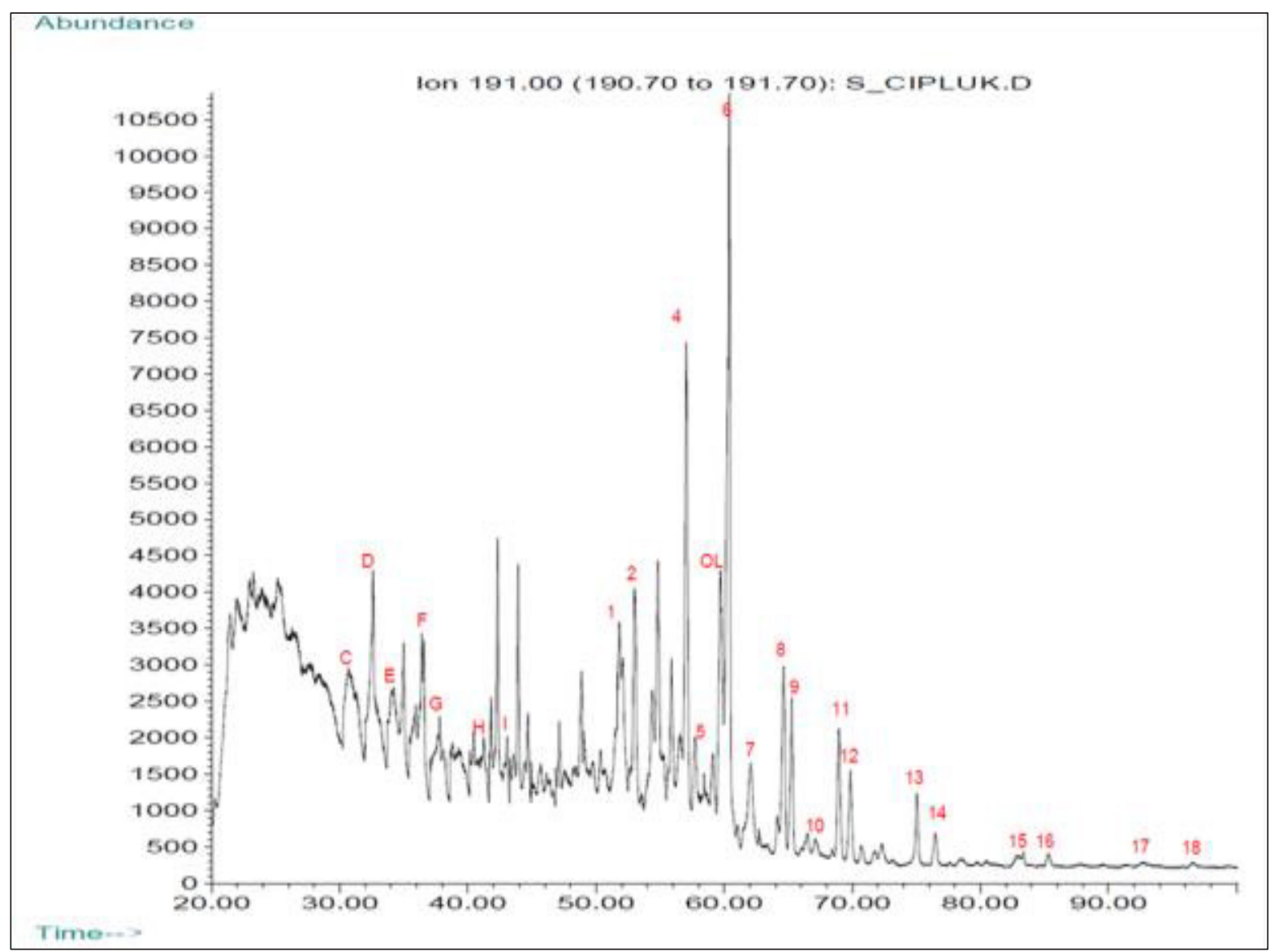

Gambar 8. Fragmentogram massa m/z 191

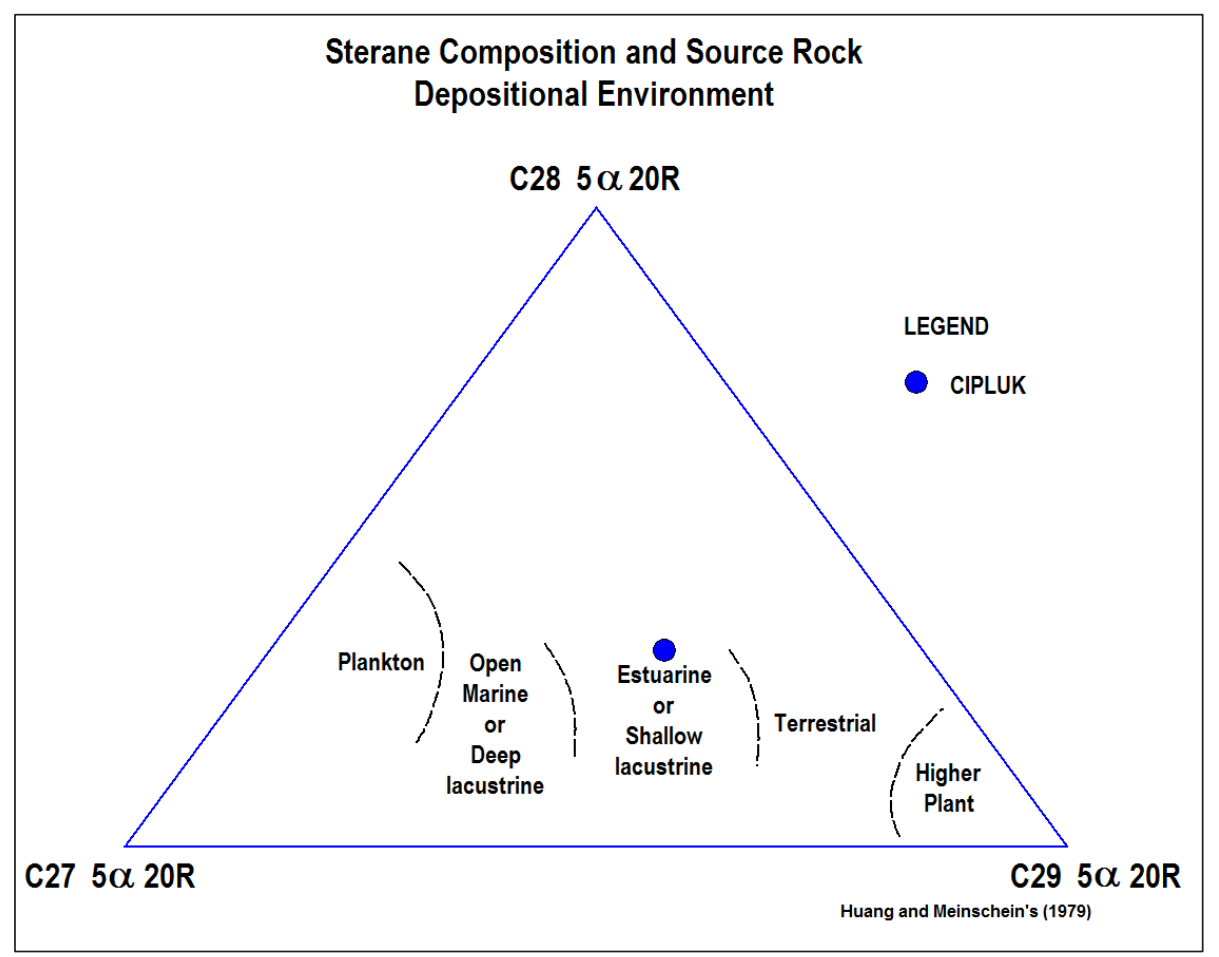

Gambar 9. Diagram komposisi sterane dan lingkungan pengendapan batuan induk rembesan minyak di daerah penelitian

(Huang dan Meinschein's, 1979 dalam Waples and Machihara, 1991). 


\section{Kematangan}

Methylphene (MPI) dihitung dari distribusi phenantheren $(\mathrm{m} / \mathrm{z} \quad 170$ dan methyhenantheres $(\mathrm{m} / \mathrm{z})$ dalam minyak. Hasil perhitungan tersebut menunjukkan bahwa conto minyak mempunyai nilai MPI yang relatif tinggi yaitu 0,79 , hal ini diperkirakan bahwa minyak berada pada tingkat matang. Berdasarkan distribusi biomarker diinterpretasikan bahwa minyak berasal dari fasies batuan induk estuarin atau lakustrin dangkal dengan organik tanaman darat yang tinggi dengan sedikit alga.

\section{Korelasi Batuan Induk dan Minyak}

Analisis GC dan GCMS ekstrak batuan induk dari Formasi Kerek belum dilakukan, namun untuk mengkorelasikan batuan induk Formasi Kerek dengan minyak Cipluk digunakan analisis yang telah dilakukan oleh peneliti terdahulu yang dilakukan di daerah Kedungjati, Semarang. Hasil analisis menunjukkan bahwa Formasi Kerek mengandung bahan organik aquatic (algal) yang kemungkinan berasal dari lingkungan marin dan mempunyai tingkat kematangan rendah (thermally immature) (Hidayat dan Fatimah, 2007).

Hasil analisis GC dan GCMS pada rembesan minyak menunjukkan bahwa minyak berasal dari batuan induk yang diendapkan pada lingkungan estuarin atau lakustrin dangkal dengan bahan organik dari tanaman darat dan batuan induk dikategorikan matang. Berdasarkan data analisis, diperkirakan rembesan minyak di lapangan Cipluk bukan berasal dari batuan induk Formasi Kerek.

\section{KESIMPULAN}

Batuan induk Formasi Kerek menunjukkan kategori rendah hingga sangat baik untuk membentuk hidrokarbon, termasuk dalam gas prone dan oil prone. Diagram Hidrogen indek versus Temperatur Maksimum menunjukkan bahwa kematangan termal conto di daerah penelitian termasuk dalam kategori belum matang hingga matang dan termasuk dalam tipe kerogen III.

Dari hasil analisis geokimia minyak bumi menunjukkan batuan induk diendapkan pada lingkungan Estuarin atau lakustrin dangkal yang material organiknya berasal dari tanaman darat yang tinggi dan sedikit alga. Rembesan minyak bumi berasal dari batuan induk yang diendapkan pada lingkungan suboksik, menunjukkan tipe kerogen III dan dapat dikategorikan minyak matang.

\section{UCAPAN TERIMA KASIH}

Penulis mengucapkan banyak terima kasih kepada tim editor yang telah membantu dalam penyempurnaan makalah dan kepada dewan redaksi atas dimuatnya makalah dalam buletin ini.

\section{DAFTAR PUSTAKA}

Connan J. and Cassou, A.M., 1980, Properties of gases and petroleum liquids derived from terrestrial kerogen at varios maturation levels. Geochemical Cosmochim. Acta 44, 1-23.

Cox, H.C., Leeuw, J.W., Schenk, P.A. et al., 1986. Bicadinane, a C30 pentacyclic isoprenoid hydrocarbon found in crude oil. Nature, pp. 316-319.

Hidayat R. dan Fatimah, 2007, Inventarisasi Kandungan Minyak dalam Batuan Daerah Kedungjati, Kabupaten Semarang, Provinsi Jawa Tengah. Proceeding Pemaparan Hasil Kegiatan Lapangan dan Non Lapangan Tahun 2007. Pusat Sumber Daya Geologi. 13 hal.

Mukhopadhyay, P. K., Wade J.A., Gruge M. A., 1995, Organic facies and maturation of Jurassic/ cretaceous rocks, and possible oil-source rock correlation based on pyrolysis of asphaltenes, Scotian Basin Canada, Org. Geochem., Vol. 22, No.1, pp. 85- 104. 


\section{MAKALAH ILMIAH}

Peters, K.E., 1986, Guidlines for evaluating petroleum source rock using programmed pyrolysis. American Association of Petroleum Geology, Bulletin, 70, p.1-36.

Peters, K.E. and Moldowan, J.M., 1993, The Biomarker Guide. Interpreting Molecular Fossils in Petroleum and Ancient Sediments, Prentice Hall, New Jersey, 363pp.

Satyana, A.H., Armandita C., 2004. Deepwater Plays of Java, Indonesia: Regional Evaluation on Opportunities and Risks. Proc. Deepwater And Frontier Exploration In Asia \& Australasia Symposium, Indonesian Petroleum Association.

Thanden R.E., Sumadirdja H., Richards P.W., Sutisna K., dan Amin T.C.,
1996, Peta Geologi Lembar Magelang dan Semarang. Skala 1:100.000. Pusat Penelitian dan Pengembangan Geologi.

Tissot, B.P. and D.H.Welte, 1984, Petroleum formation and occurrence, Springer Verlag, Berlin, 699 pp.

Waples D.W. (1985), Geochemistry in Petroleum Exploration, International Human Resources Developmen Co., Boston.

Waples, D.W. and Machihara, 1991. Biomarker for Geologist-A Practical Guide to the Application of Steranes and Triterpanes in Petroleum Geology. American Association of Petroleum Geologists. Methods in Exploration Series, 9, 91pp.

\begin{tabular}{|ll|}
\hline Diterima & $:$ 1 Juni 2016 \\
Direvisi & $: 19$ Juli 2016 \\
Disetujui & $: 16$ Agustus 2016 \\
\hline
\end{tabular}

